\title{
Vegetables Marketing Scenario and Trends in Prices and Arrivals of Vegetables in Different Markets of South 24 Parganas District of West Bengal, India
}

\author{
Prasenjit Kundu $^{1}$, Nayan Kishor Adhikary ${ }^{2}$ and Abhijit Ghosal ${ }^{1}$ \\ ${ }^{1}$ Sasya Shyamala Krishi Vigyan Kendra, Ramakrishna Mission Vivekananda University, \\ Narendrapur - 700103, West Bengal, India \\ ${ }^{2}$ Institute of Agricultural Science, University of Calcutta, 51/2, Hazra Road, Kolkata - \\ 700019, West Bengal, India \\ *Corresponding author
}

\section{A B S T R A C T}

Keywords

Trends, Prices,

Arrivals,

Vegetables,

Marketing

efficiency

Article Info

Accepted:

15 November 2019

Available Online:

10 December 2019
Vegetables are seasonal crops and their supply in the town market is subjected numerous to natural vagaries. Further, due to their perishable nature, they have to be dispatched to market without delay. The supply of vegetable on one hand and the demand for them on the other, at a particular time and market, determines the price. The changes in these determinants over a period of a time will affect the price. High seasonality in prices is generally observed for vegetables. The magnitude of such seasonal fluctuation could be reduced by storing the vegetable for off-season sales. Further, the price spread of vegetables depends on the length of marketing channels and their marketing efficiency. The analysis of such seasonal and other components of time series data on wholesale prices of vegetables and price spread, marketing efficiency of different marketing channel of vegetable are very much important for the policy makers.

\section{Introduction}

The importance of horticultural crops, especially fruits and vegetables in improving the nutritional security is increasing day by day. There is a need to increase the production of nutritious food in a sustainable manner and improve farm income to ensure household food and nutritional security, while conserving the natural resource base. Growing of vegetables is 4 to 8 times more remunerative than cereals and its cultivation generates substantial employment in the rural areas. In our country $90-98 \%$ of vegetables are found to 
be sold and used afresh. Although India is the second largest producer of vegetables in the world yet we cannot fulfill our domestic demand of vegetables. Vegetables like Brinjal, Cauliflower, Cabbage, Radish and Cucurbits are now produced almost round the year in some parts of the country. Sky-high magnitude in prices during off season lead to uncertainty in vegetable growing farmers' income. Mittal (2007) observed that the increasing share of high value commodities in the consumption basket of households, higher incomes and urbanisation, changing lifestyles, market integration and trade liberalisation at global level have led to an increase in the demand for horticulture products in India. Therefore, an attempt has been made to study the pattern and behavior of arrival and price. Sankerlalguru (2001) reported that an efficient agricultural marketing is essential for the development of the agricultural sector. Marketing of vegetable crops is complex especially because of perishability, seasonality and bulkiness. Their bulkiness makes the handling and transportation a difficult task, leading to huge post-harvest a loss which is estimated at around Rs. 23,000 crore or nearly $35 \%$ of the total annual production (CII, Mckinsey, 1997). The cultivation of fruits and vegetables is generally concentrated around towns and cities, so that they can be harvested and transported to the nearby market immediately and in fresh form. Inadequate market infrastructure and too many intermediaries between the producers and consumers leads to high marketing costs, resulting in lower share of producer in the consumer's rupee. The price spread along the marketing channel is directly proportional to the number of market intermediaries involved along the channel (Gupta and Rathore, 1998). Vegetables, barring cabbage and cauliflower, are mainly sold through the commission agents at the market, who intern transports the produce to the distant markets and makes his margin, traditional flowers are self marketed at the wholesale auction centers (Subrahmanyam, 1989). Some studies have shown that producers' share in consumers' rupee is comparatively lower for perishable crops (Saikia, 1985; Ashturker and Deole, 1985).The lack of market intelligence about the potential market and fluctuating pattern of arrivals and prices in important regional markets of West Bengal further adds to the woes of the farmers. Against this backdrop the present study was undertaken to gain insight into the behaviour of market arrivals and wholesale prices of important vegetable crops (Chilli, Cucurbits, Tomato, Cabbage, Brinjal and Cauliflower etc.) in some selected markets of South 24 Parganas district of West Bengal.

\section{Materials and Methods}

The process of selecting the study area, details about the study area, data collection methodology and analytical techniques which helps us to attain the objectives of the study.

West Bengal as well as the Eastern part of India is producing the vegetable in a mammoth amount since last decades. Both the traditional as well as the new modern technologies are used for the intensified growth of vegetable sector in this region. South 24 Parganas district has been selected purposively for its normal average yield per acreage area in case of vegetable production. From South 24 Parganas district, five blocks were selected purposively. The selected blocks were Budge Budge-I, Baruipur, Bhangore-II, Diamond Harbour-I and Falta.

The centre of the study was on the input and output data of vegetables as well as the arrivals of the quantity of product in the market and the prices of the produce throughout the year obtained from the respondents of the selected market areas of 5 blocks. Multistage sampling design was used for the identification of the respondents. 
South 24 Parganas district of West Bengal was selected purposively at first in this technique. Two markets were nominated from each block of South 24 Parganas (Mallikpur and Notunhaat market from Budge Budge-I block; Baruipur and Surjapur market from Baruipur block; Charu Market, Bhangore market from Bhangore-II block, Basul Danga Haat and Diamond Harbour-I station road bazar market from Diamond Harbour-I block and Sohsorar haat and Fatepur market from Falta block) based on the size of the vegetable markets. In the fourth full stage, 30 respondents were selected from the each market with 20 producers, 5 wholesalers and 5 retailers (Table 1 ).

For achieving the purposes of the work the primary along with secondary data in quantitative and qualitative nature was collected. Primary records was prevailed from the respondents through personal interview on the basis of the pre structured survey schedule.

After collection of the survey data the further step was to process the raw figures and arrange them in a tabular form in excel sheet. The collected data were transferred under different heads of separate square sheets with respect of different size groups.

Subsequently different tables were prepared with different goals to achieve the objectives of the studies. The entire information of the survey was presented with a view to provide a base for purposeful analysis and interpretation of the findings.

For the present study, the secondary data have been collected and used from different secondary sources, viz., (1) West Bengal State Marketing Board (2) Statistical Abstract of West Bengal (3) National Horticultural Database (4) Directorate of marketing and inspection, Government of India. From the above sources the data on prices of different vegetables viz., Brinjal, Chili, Cucurbits, Tomato, Cauliflower and Cabbage have been collected from different markets of various blocks for the period 2017 and 2018.

Trend is the long term direction in prices and arrivals which is influenced by the steady change in commodity demand and supply. Trend component of time series will be calculated by using least square equation:

$\mathrm{Y}_{\mathrm{t}}=\mathrm{a}_{0}+\mathrm{a}_{1} \mathrm{t}$

Where,

$Y_{t}=$ value of the variable at time $t$,

$\mathrm{a}_{0}=$ constant value

$\mathrm{a}_{1}=$ slope

$\mathrm{t}=$ Time variable $(1,2,3 \ldots, \mathrm{n})$

The change in arrivals is mainly caused by the seasonal nature of production. The other reasons for seasonality in arrivals of vegetables are poor storage facilities and perishable nature of the product. The ratio to trend method has been employed in the study to compute the seasonal indices. The method used has the following procedures.

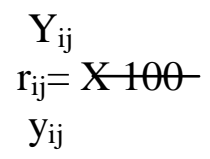

where,

$\mathrm{r}_{\mathrm{ij}}=$ seasonal component.

$Y_{i j}=$ observation for the $j^{\text {th }}$ month in the $i^{\text {th }}$ year

$\mathrm{y}_{\mathrm{ij}}=$ corresponding trend value obtained by using least square method. 
The sum of the seasonal indices should be 1200. If it is greater or less than 1200 then adjust it using a correction factor

$K=1200 / S$

Where,

$\mathrm{K}=$ Correction factor

$\mathrm{S}=$ Sum of seasonal indices

The movement of goods from producer to consumers at the lowest possible cost, consistent with the provision of services desired by the consumer, may be termed as efficient marketing. Shepherd equation has been used to calculate the marketing efficiency of different marketing channels of different vegetables. This method eliminates the problem of measurement of value added.

$\mathrm{ME}=\underline{\mathrm{V}}_{\mathrm{I}}-1$

Where,

$\mathrm{ME}=$ Index of marketing efficiency

$\mathrm{V}=$ Value of goods sold (consumer rice)

$\mathrm{I}=$ Total marketing cost.

Generally, high marketing cost and margins are considered to be indicator of inefficiency in the marketing process. Some other factors like place of production, time of production, season of production cause a high proportion of marketing cost.

\section{Results and Discussion}

The vegetables accounts largest share in terms of area as well as production (Fig. 1) among the horticultural crops produced in India. Its share in the total horticultural crops was 60.84 and $39 \%$ in production and area respectively
(NHB, 2017-18) so the vegetable sector accounts major share in terms of Area and production in horticultural context (Fig. 2 and $3)$.

The changes in area, production and yield of major vegetables in India were due to the technological improvements, developmental activities, price trends and impact of domestic prices. The change in average area, production and productivity of major vegetables in India in the last two decades has been presented in Table 2. Area under vegetables in India has increased from 5171 thousand hectares during triennium ending (TE) 2017 to 7478.1 thousand hectares during TE 2018. Similar trend in production was observed in case of Tomato, Cauliflower, Cabbage, Chilli, Cucurbits and Brinjal and the production has more than doubled, Further, the Compound Growth Rate (CGR) of area under these vegetables were higher than that of CGR of yield. This suggests that increase in vegetables production has primarily because of area expansion.

A similar trend was observed in case of other vegetables in the district of South 24 Parganas (Table 3). The production of Tomato increased more than threefold and production of cole crops (Cauliflower and Cabbage) has increased more than five times between 2017 and 2018. Except Cabbage the CGR of area under Chilli, Brinjal, Tomato and Cauliflower were higher than that of CGR of yield, which indicates increase in production was primarily contributed by area expansion.

The trend in anytime series especially marking about the general pathway of direction which denote the change over a period of time. Trend in price component is naturally affected by changing of demand also that may be due to change in population, habits customs, income and establishment of processing industries etc. Not only that, it (Price trend) also affected by 
production technology, market arrivals and side by side by the adjustment in supply arising out of development of cold storage and marketing facilities. The arrival trend is generally affected by the production and by the price. The estimated values for arrivals (A) and prices (P) for the period from 2017-18 of different Vegetables.

Positive increasing approach or trend in arrival and whole-sale price of Tomato in all the markets of five blocks (Table 4). Arrival of Tomato was recorded maximum in BhangoreII market (1867.7MT) and there was an upliftment in arrival of tomato per year, it can be inferred from the study. The positive arrival trend was mainly emphasized due to expansion of cultivable area and followed by improved modern scientific technology resulting high production, high productivity and better marketable surplus. The same picture was depicted in case of Wholesale price also. It can be reported from the survey that the rate of increment in Wholesale price of about rupees 23.5 per quintal per year.

Price trend of Cauliflower in different markets of various blocks of South 24 Parganas showed that, Falta has the highest increasing trend than others. In Bhangore-II Market highest positive increasing arrival trend was observed (Table 5). This is as because Bhangore-II is a very nearest metropolitan city i.e., Kolkata and nearest to Airport also which resulted demand for vegetables is always very high in the city.

From the study, it can be disclosed that the trend of prices and arrivals of Cabbage showed increasing trend in arrival and whole sale prices of Cabbage in all the markets during the survey period i.e. 2017-18. The observation based on the trend depicted that price and arrivals of Cabbage in different markets various blocks of this district is quite encouraging (Table 6). The study indicated that Cabbage arrivals especially in the Bhangore-II wholesale market have increased too sharply over the time period. It was concluded from the results of survey that Cabbage arrival has increased by $212.7 \mathrm{MT}$ per year. The increase in wholesale prices was much higher in the Diamond Harbour-I market than others. The increase in arrival attributed to the higher production due to improvisation of new varieties whereas the increase in price trend can be explained as due to change in demand for the crop.

Cucurbits is not produced in South 24 Parganas district for direct commercial purpose, but demand for these type of vegetables in this locality is always very high due to its multipurpose use. The wholesale price pattern of Cucurbits signified an increasing trend and Budge Budge-I market showed highest trend in per quintal price of Cucurbits (Table 6). In case of arrival trend pattern Bhangore-II occupied the first position than others with an increase of 123.6 MT.

Chilli is an important crop and is produced in all the blocks of South 24 Parganas. Due to its long storage life its arrival in market is continuous throughout the year. From the study it can be revealed that trends in prices and arrivals were positive for this vegetable during the survey period (2017-18). Increasing population creating huge demand of Chillies that implied with general price rise which resulted the increasing trends in wholesale prices. That positive trend in prices signified that the demand for Chillies outweighs its supply and also having positive net effect on price.

Trend in wholesale Chilli price was denoted highest in Bhangore-II market compared to the other markets in this district (Table 8). The Bhangore-II market reported as highest trend of arrivals during the reference period. Out of all markets studied, Bhangore-II is the biggest 
market, and serves into the metropolitan city that is in Kolkata where per capita income is much high.

A positive trend in arrival and whole sale prices of Brinjal was recorded during reference period i.e. 2017-18 in all the markets (Table 9). In Bhangore-II arrival of Brinjal showed the highest trend. Increase in arrival may be attributed to the higher production due to the introduction of high productive new hybrid varieties.

Seasonality is an important issue of arrivals in the markets and their consequence on price. Seasonality in the arrivals and prices are those changes, which occur regularly every year as a result of changes in season. These variations may be primarily due to the seasonal production, poor cold storage facilities and lack of retention power of vegetable growers.

High seasonal fluctuations affect income of the grower adversely. Large arrivals in the post-harvest period create glut conditions in the market resulting in lowering of prices and causing considerable loss to the vegetable growers. The magnitude of price variation in different vegetables is different due to the seasonal nature of arrivals and perishable nature of the product.

The index of seasonal price of Tomato was lowest in the month of March followed by February in all the market except Falta. The wholesale prices Tomato begin to decrease from the month of December and continued low up to the month of March (Fig. 4). The price index found highest in the month October followed by September in all the market except Budge Budge-I market.

Therefore, it can be proposed that farmers should adopt such type of varieties which can be harvested during the months of July to October. Maximum arrival of Chilli was recorded from the month of July to October and again from January to March.

The seasonal price variation of Cauliflower found lowest in the month January and it continued upto April. It can be inferred that seasonal variation in prices due to the arrival pattern of Chilli. Fresh arrival of Chilli occurred from October to March. The study denotes that the highest arrival was depicted in December and January. So, the analysis revealed that the period from April to September was termed as a lean period for arrivals of cauliflower (Fig. 5). The arrival starts its speed up from October and the maximum arrivals of Cauliflower were found during the period of October to February in the various markets which create gluts.

Cabbage, the nature of seasonal production resulted changes in arrivals and the other reasons are poor storage facilities and perishable nature of the crop and it was reported that seasonal price variation of Cabbage was the lowest in the month of January.

Fresh arrival of cabbage starts from the month of October and it continues upto March (Fig. $6)$. The maximum arrival was observed during the period of October to February and resulting gluts in the markets. The price index was higher in the month July and it was suggested that the favorable period for to sell out in the markets with higher price during the period of July to December.

Due to long storage life of cucurbits, the seasonality effect on arrivals and prices was less than other vegetables which undertaken in the study as like Brinjal, Cauliflower, Cabbage and Tomato.

December to March is the pick time when the cucurbits found in the markets in abundantly. It can be reported that, the seasonality in 
arrivals is the net result of seasonal production and marketable surplus. Market arrivals of cucurbits were reported in higher quantity from month of January onwards till March.

Cucurbits which were pre-sown comes in the market from the month January but generally Cucurbits which cultivated as per normal time came in markets in March in huge quantities.

The arrival was in downward pattern was recorded more prominently from the month July to September. Thus it can conclude that the arrivals of cucurbits showed a mixed pattern. Arrivals of Cucurbits showed the fluctuations in an unsystematic manner except from the months of January to March which result increasing pattern in arrivals and decreasing pattern during the months of May and June (Fig. 7).

Pattern of market arrivals and the influence of previous period price of cucurbits causes seasonal variation in price.

It was reported that, the indices of seasonal price variation of Chilli was recorded lowest in the month February followed by the month of January and March respectively in all the markets except Budge Budge-I, where seasonal index was lowest in January followed by February. The overall market survey about Chilli revealed that the price of Chilli was low in the months of January to April and in the month of December. Out of those months the lowest price was denoted in the month of February followed by the months of January and March.

The arrivals of Chilli in the markets in lower amount were recorded in the months of April to September which can be termed as lean season period (Fig. 8). The wholesale price of Chilli was lifted from the months of May to till November whereas highest market price recorded in the month of October owing to greater demand during that period.

From the study of referral period it was observed that the indices of market arrivals of Brinjal were higher from October onwards till April. Among these months, in the month March Brinjal loaded in the market with huge quantity. The downward movement arrival pattern was also make prominence from the month of May and it continued upto October. Thus the arrivals of Brinjal signified a mixed pattern.

Table.1 Multipurpose sampling method was used to select the respondent

\begin{tabular}{|c|c|c|}
\hline Parameters & Name & Sampling type \\
\hline $\begin{array}{c}\text { Selection of } \\
\text { District }\end{array}$ & South 24 Parganas & Purposive Sampling \\
\hline $\begin{array}{c}\text { Selection of Block } \\
\begin{array}{c}\text { Selection of } \\
\text { markets }\end{array}\end{array}$ & $\begin{array}{c}2 \text { markets of each block } \\
(2 \times 5=10 \text { markets })\end{array}$ & Purposive Sampling \\
\hline $\begin{array}{c}\text { Selection of } \\
\text { respondents }\end{array}$ & $\begin{array}{c}30 \text { respondents of each market } \\
\text { (20 farmers }+5 \text { wholesaler }+5 \text { retailer })\end{array}$ & Purposive Sampling \\
i.e. 300 respondents & \\
\hline
\end{tabular}


Table.2 Area, Production and productivity of different Vegetables in India

\begin{tabular}{|c|c|c|c|c|c|c|c|c|c|}
\hline \multirow[t]{2}{*}{ Crop } & \multicolumn{2}{|c|}{ Area $(000$, ha) } & & \multicolumn{3}{|c|}{$\begin{array}{c}\text { Production } \\
\text { (Million tonnes) }\end{array}$} & \multicolumn{3}{|c|}{ Yield (Quintal/ha) } \\
\hline & TE 2017 & TE 2018 & CGR & $\begin{array}{c}\text { TE } \\
2017\end{array}$ & $\begin{array}{r}\mathrm{TE} \\
2018\end{array}$ & $\begin{array}{c}\mathrm{CG} \\
\mathrm{R}\end{array}$ & $\begin{array}{c}\text { TE } \\
2017\end{array}$ & $\begin{array}{r}\text { TE } \\
2018\end{array}$ & $\begin{array}{c}\mathrm{CG} \\
\mathrm{R}\end{array}$ \\
\hline Chilli & 1006.4 & 1699.3 & 3.42 & 15.61 & $\begin{array}{c}30.7 \\
5\end{array}$ & 4.52 & $\begin{array}{c}155.3 \\
9\end{array}$ & $\begin{array}{c}180.9 \\
9\end{array}$ & 1.06 \\
\hline Cucurbits & 316.23 & 758.67 & 5.42 & 3.43 & $\begin{array}{c}10.8 \\
1\end{array}$ & 7.03 & $\begin{array}{c}108.5 \\
5\end{array}$ & $\begin{array}{c}142.1 \\
4\end{array}$ & 1.52 \\
\hline Tomato & 300.7 & 564.67 & 3.00 & 4.61 & 9.47 & 3.97 & 153.0 & $\begin{array}{c}167.7 \\
3\end{array}$ & 0.96 \\
\hline Brinjal & 297.40 & 571.27 & 4.22 & 4.40 & $\begin{array}{c}10.0 \\
5\end{array}$ & 5.54 & $\begin{array}{c}147.8 \\
0\end{array}$ & $\begin{array}{c}176.0 \\
0\end{array}$ & 1.27 \\
\hline $\begin{array}{c}\text { Cauliflow } \\
\text { er }\end{array}$ & 183.10 & 256.13 & 2.07 & 3.00 & 5.70 & 4.4 & $\begin{array}{c}163.8 \\
2\end{array}$ & $\begin{array}{c}222.7 \\
5\end{array}$ & 2.29 \\
\hline Cabbage & 216.75 & 306.63 & 2.4 & 3.31 & 5.57 & 4.44 & $\begin{array}{c}152.2 \\
1\end{array}$ & $\begin{array}{c}181.6 \\
0\end{array}$ & 2.00 \\
\hline
\end{tabular}

Table.3 Area, Production and productivity of different Vegetables in South 24 Parganas

\begin{tabular}{|c|c|c|c|c|c|c|c|c|c|}
\hline Crop & \multicolumn{2}{|c|}{$\begin{array}{c}\text { Area } \\
\text { (000,ha) }\end{array}$} & & \multicolumn{3}{c|}{$\begin{array}{c}\text { Production (thousand } \\
\text { tonnes) }\end{array}$} & \multicolumn{2}{c|}{$\begin{array}{c}\text { Yield } \\
\text { (Quintal/ha) }\end{array}$} & \\
\hline & TE & TE & CGR & TE & TE & CGR & TE & TE & CG \\
& 2017 & 2018 & & 2017 & 2018 & & 2017 & 2018 & R \\
\hline Chilli & 215.4 & 376.4 & 3.65 & 4279.4 & 8350.9 & 4.21 & 197 & 228 & 0.67 \\
\hline Tomato & 69.38 & 153.1 & 6.34 & 716.6 & 2730.4 & 11.3 & 103 & 178 & 4.69 \\
\hline Brinjal & 29.1 & 50.7 & 11.3 & 295.8 & 893.2 & 15.6 & 253 & 190 & 2.77 \\
\hline Cauliflower & 26.1 & 73.5 & 7.96 & 265.3 & 1988 & 16.1 & 1016 & 2700 & 7.52 \\
\hline Cabbage & 26.09 & 66.2 & 7.16 & 265.3 & 1868.8 & 15.6 & 1016 & 2520 & 7.21 \\
\hline
\end{tabular}

Table.4 The trends in price and arrival of Tomato

\begin{tabular}{|c|c|c|c|c|c|}
\hline $\begin{array}{c}\text { Trend } \\
\text { equation }\end{array}$ & Baruipur & $\begin{array}{c}\text { Budge } \\
\text { Budge-I }\end{array}$ & Bhangore-II & $\begin{array}{c}\text { Diamond } \\
\text { Harbour-I }\end{array}$ & Falta \\
\hline Price (P) & 430.67 & 435.42 & 460.2 & 405.4 & 430.1 \\
\hline Arrival (A) & 485.6 & 697.7 & 1867.7 & 83.5 & 980.8 \\
\hline
\end{tabular}


Table.5 The trends in prices and arrival of cauliflower

\begin{tabular}{|c|c|c|c|c|c|}
\hline $\begin{array}{c}\text { Trend } \\
\text { equation }\end{array}$ & \multicolumn{5}{|c|}{ Markets } \\
\hline & Baruipur & Budge Budge-I & Bhangore- & $\begin{array}{c}\text { Diamond } \\
\text { II }\end{array}$ & Farbour-I \\
\hline & & & & & \\
\hline Price (P) & 414.4 & 420.0 & 418.1 & 418.4 & 424.8 \\
\hline Arrival (A) & 484.5 & 725.7 & 1786.6 & 87.5 & 1034.8 \\
\hline
\end{tabular}

Table.6 The trends in prices and arrival cabbage

\begin{tabular}{|c|c|c|c|c|c|}
\hline $\begin{array}{c}\text { Trend } \\
\text { equation }\end{array}$ & Baruipu & Budge Budge-I & Bhangore-II & $\begin{array}{c}\text { Diamond } \\
\text { Harbour-I }\end{array}$ & Falta \\
\hline & r & & & & \\
\hline Price (P) & 429.9 & 424.5 & 467.5 & 410.3 & 412.4 \\
\hline Arrival (A) & 2723.4 & 712.7 & 1706.8 & 84.5 & 1012.8 \\
\hline
\end{tabular}

Table.7 The trends in prices and arrival of cucurbits

\begin{tabular}{|c|c|c|c|c|c|}
\hline \multirow{2}{*}{$\begin{array}{c}\text { Trend } \\
\text { equation }\end{array}$} & & & Markets & & \\
\hline & $\begin{array}{c}\text { Baruipu } \\
\mathbf{r}\end{array}$ & Budge Budge-I & Bhangore-II & $\begin{array}{l}\text { Diamond } \\
\text { Harbour-I }\end{array}$ & Falta \\
\hline Price (P) & 489.0 & 497.8 & 522.7 & 445.0 & 456.7 \\
\hline Arrival (A) & 1588.2 & 2244.7 & 14170.0 & 138.6 & 2674.4 \\
\hline
\end{tabular}

Table.8 The trends in prices and arrival of different chilli

\begin{tabular}{|c|c|c|c|c|c|}
\hline $\begin{array}{c}\text { Trend } \\
\text { equation }\end{array}$ & Baruipur & Budge Budge-I & Bhangore-II & Diamond Harbour-I & Falta \\
\hline & & & & & \\
\hline Price (P) & 430.0 & 505.8 & 525.6 & 445.8 & 420.4 \\
\hline $\begin{array}{c}\text { Arrival } \\
\text { (A) }\end{array}$ & 4725.5 & 13044.0 & 29705.0 & 1145.4 & 18174.0 \\
\hline
\end{tabular}

Table.9 The trends in prices and arrival of brinjal

\begin{tabular}{|c|c|c|c|c|c|}
\hline Trend equation & Baruipur & $\begin{array}{c}\text { Markets } \\
\text { Budge }\end{array}$ & $\begin{array}{c}\text { Bhangore- } \\
\text { Budge-I }\end{array}$ & $\begin{array}{c}\text { Diamond } \\
\text { Harbour-I }\end{array}$ & Falta \\
\hline Price (P) & 425.14 & 424.8 & 512.2 & 435.4 & 453.2 \\
\hline Arrival (A) & 488.3 & 752.7 & 1504.7 & 88.5 & 1012.8 \\
\hline
\end{tabular}


Table.10 The marketing efficiency of different marketing channels of tomato

\begin{tabular}{|c|c|c|c|c|}
\hline Particulars & \multicolumn{4}{c|}{ Marketing channels } \\
\hline & I & II & III & IV \\
\hline Quantity produced and sold (qt) & 4200 & 21000 & 1000 & 8000 \\
\hline Quantity sold (\%) & 11.7 & 64.0 & 3.8 & 20.5 \\
\hline Value of produce sold (Consumer price) & 410 & 412 & 330 & 410 \\
\hline Marketing cost (I) (Rs./q) & 128 & 139 & 50 & 145 \\
\hline Marketing efficiency (ME=V/I-1) & 2.2 & 1.96 & 5.6 & 1.82 \\
\hline Farmer Price (Rs./q) & 282 & 273 & 280 & 265 \\
\hline Producer share in consumer's Price (\%) & 68 & 66 & 84 & 64 \\
\hline
\end{tabular}

Table.11 The price spread of marketing channels II of tomato

\begin{tabular}{|c|c|c|}
\hline Price spread (South 24 Parganas) & Rs. & Percentage \\
\hline \multicolumn{3}{|c|}{ Producer } \\
\hline Transportation cost & 25 & 6.1 \\
\hline Unloading and clearing cost & 10 & 2.4 \\
\hline Producer's margin & 273 & 66.2 \\
\hline Producer's price & 308 & 74.8 \\
\hline \multicolumn{3}{|c|}{ Wholesaler } \\
\hline Commission agent & 14 & 3.4 \\
\hline Market charge & 7.5 & 1.8 \\
\hline Transportation cost & 10 & 2.4 \\
\hline Storage cost & 10 & 2.4 \\
\hline Wholesaler's margin & 16 & 3.9 \\
\hline Wholesaler's price & 365.50 & 88.7 \\
\hline \multicolumn{3}{|c|}{ Retailer } \\
\hline Retailer' margin & 18 & 4.4 \\
\hline Market charge & 7.5 & 1.8 \\
\hline Weighing & 1 & 0.2 \\
\hline Transportation cost & 10 & 2.4 \\
\hline Loading and unloading & 10 & 2.4 \\
\hline Consumer's price & 412 & 100 \\
\hline
\end{tabular}

Table.12 The efficiency of different marketing channels of cauliflower

\begin{tabular}{|c|c|c|c|c|}
\hline \multirow{2}{*}{ Particulars } & \multicolumn{4}{|c|}{ Marketing channels } \\
\cline { 2 - 5 } & I & II & III & IV \\
\hline Quantity produced and sold (qt) & 2000 & 12000 & 1000 & 6000 \\
\hline Quantity sold (\%) & 8.52 & 59.8 & 5.2 & 26.48 \\
\hline Value of produce sold (Consumer price) & 485 & 475.50 & 470 & 535.50 \\
\hline Marketing cost (I) (Rs./q) & 130 & 148.50 & 40 & 180 \\
\hline Marketing efficiency(ME=V/I-1) & 2.86 & 2.16 & 12.6 & 1.84 \\
\hline Farmer Price (Rs./q) & 355 & 327 & 430 & 355 \\
\hline Producer share in consumer's Price (\%) & 73.1 & 68.7 & 91.4 & 66.2 \\
\hline
\end{tabular}


Table.13 The Price Spread of marketing channels II of Cauliflower

\begin{tabular}{|c|c|c|}
\hline $\begin{array}{c}\text { Price spread (South } 24 \\
\text { Parganas) }\end{array}$ & Rs. & Percentage \\
\hline \multicolumn{3}{|c|}{ Producer } \\
\hline Transportation cost & 24 & 5 \\
\hline $\begin{array}{l}\text { Unloading and clearing } \\
\text { cost }\end{array}$ & 12 & 2.5 \\
\hline Producer’s margin & 327 & 68.8 \\
\hline Producer's price & 363 & 76.3 \\
\hline \multicolumn{3}{|c|}{ Wholesaler } \\
\hline Commission agent & 12 & 2.5 \\
\hline Market charge & 7.5 & 1.6 \\
\hline Transportation cost & 15 & 3.2 \\
\hline Storage cost & 18 & 3.8 \\
\hline Wholesaler's margin & 16 & 3.4 \\
\hline Wholesaler's price & 431.50 & 90.7 \\
\hline \multicolumn{3}{|c|}{ Retailer } \\
\hline Retailer' margin & 15.5 & 3.3 \\
\hline Market charge & 7.5 & 1.6 \\
\hline Weighing & 1 & 0.2 \\
\hline Transportation cost & 10 & 2.1 \\
\hline Loading and unloading & 10 & 2.1 \\
\hline Consumer's price & 475.50 & 100 \\
\hline
\end{tabular}

Table.14 The efficiency of different marketing channels of Cabbage

\begin{tabular}{|c|c|c|c|c|}
\hline Particulars & \multicolumn{4}{|c|}{ Marketing channels } \\
\hline & I & II & III & IV \\
\hline Quantity produced and sold (qt) & 2500 & 12500 & 700 & 3000 \\
\hline $\begin{array}{c}\text { Quantity sold (\%) } \\
\text { Value of produce sold( consumer } \\
\text { price) }\end{array}$ & 15.4 & 68.2 & 3.2 & 13.2 \\
\hline Marketing cost (I) (Rs./q) & 125 & 682 & 620 & 720 \\
\hline Marketing efficiency (ME=V/I-1) & 4.36 & 230 & 38 & 240 \\
\hline Farmer Price (Rs/q) & 545 & 452 & 582 & 480 \\
\hline $\begin{array}{c}\text { Producer share in consumer's Price } \\
(\%)\end{array}$ & 81.3 & 66.2 & 93.8 & 66.6 \\
\hline
\end{tabular}


Table.15 The Price Spread of marketing channels II of Cabbage

\begin{tabular}{|c|c|c|}
\hline Price spread (South 24 Parganas) & Rs. & Percentage \\
\hline \multicolumn{3}{|c|}{ Producer } \\
\hline Transportation cost & 30 & 4.4 \\
\hline Unloading and clearing cost & 10 & 1.5 \\
\hline Producer's margin & 452 & 66.3 \\
\hline Producer's price & 492 & 72.1 \\
\hline \multicolumn{3}{|c|}{ Wholesaler } \\
\hline Commission agent & 32 & 4.7 \\
\hline Market charge & 7.5 & 1.1 \\
\hline Transportation cost & 22 & 3.2 \\
\hline Storage cost & 16 & 2.3 \\
\hline Wholesaler's margin & 36 & 5.3 \\
\hline Wholesaler's price & 605.50 & 88.8 \\
\hline \multicolumn{3}{|c|}{ Retailer } \\
\hline Retailer' margin & 42 & 6.2 \\
\hline Market charge & 7.5 & 1.1 \\
\hline Weighing & 1 & 0.1 \\
\hline Transportation cost & 12 & 1.8 \\
\hline Loading and unloading & 14 & 2.1 \\
\hline Consumer's price & 682 & 100 \\
\hline
\end{tabular}

Table.16 The Marketing efficiency of different marketing channels of Cucurbits

\begin{tabular}{|c|c|c|c|c|c|}
\hline \multirow{2}{*}{ Particulars } & \multicolumn{5}{|c|}{ Marketing channels } \\
\cline { 4 - 7 } & I & II & III & IV & V \\
\cline { 4 - 7 } & & & & & \\
\hline Quantity produced and sold (qt) & 320 & 40 & 30 & 5 & 70 \\
\hline $\begin{array}{c}\text { Quantity sold (\%) } \\
\text { Value of produce sold (Consumer } \\
\text { price) }\end{array}$ & 66.4 & 7.4 & 7.5 & 2.2 & 16.5 \\
\hline Marketing cost (I) (Rs./q) & 235 & 160 & 135 & 35 & 240 \\
\hline Marketing efficiency (ME=V/I-1) & 3.31 & 5.04 & 5.81 & 25 & 3.22 \\
\hline Farmer Price (Rs./q) & 780 & 807 & 785 & 865 & 775 \\
\hline $\begin{array}{c}\text { Producer share in consumer's Price } \\
(\%)\end{array}$ & 79 & 82 & 84.9 & 96 & 78.7 \\
\hline
\end{tabular}


Table.17 The Price Spread of marketing channels of Cucurbits

\begin{tabular}{|c|c|c|}
\hline Price spread (South 24 Parganas) & Rs. & Percentage \\
\hline \multicolumn{3}{|c|}{ Producer } \\
\hline Transportation cost & 21 & 2.1 \\
\hline Unloading and clearing cost & 10 & 1 \\
\hline Producer's margin & 780 & 76.8 \\
\hline Producer's price & 811 & 79.9 \\
\hline \multicolumn{3}{|c|}{ Wholesaler } \\
\hline Commission agent & 16 & 1.6 \\
\hline Market charge & 7.5 & 0.7 \\
\hline Transportation cost & 10 & 0.9 \\
\hline Storage cost & 10 & 0.9 \\
\hline Wholesaler's margin & 79 & 7.8 \\
\hline Wholesaler's price & 933.50 & 92 \\
\hline \multicolumn{3}{|c|}{ Retailer } \\
\hline Retailer's margin & 53 & 5.2 \\
\hline Market charge & 7.5 & 0.7 \\
\hline Weighing & 1 & 0.1 \\
\hline Transportation cost & 10 & 0.9 \\
\hline Loading and unloading & 10 & 0.9 \\
\hline consumer's price & 1015 & 100 \\
\hline
\end{tabular}

Table.18 The Price Spread of marketing channels of Chilli

\begin{tabular}{|c|c|c|}
\hline Price spread (South 24-Parganas) & Rs. & Percentage \\
\hline & Producer & \\
\hline Transportation cost & 25 & 2.4 \\
\hline Unloading and clearing cost & 10 & 0.9 \\
\hline Producer's margin & 830 & 79.8 \\
\hline Producer's price & 865 & 83.1 \\
\hline & Wholeseler & \\
\hline Commission agent & 16 & 01.5 \\
\hline Market charge & 7.5 & 0.7 \\
\hline Transportation cost & 10 & 0.9 \\
\hline Storage cost & 10 & 0.9 \\
\hline Wholesaler's margin & 83 & 7.9 \\
\hline Wholesaler's price & 958.50 & 92.1 \\
\hline Retailer's margin & Retailer & \\
\hline Market charge & 53.0 & 5.09 \\
\hline Weighing & 7.5 & 0.72 \\
\hline Transportation cost & 1 & 0.09 \\
\hline Loading and unloading & 10 & 0.96 \\
\hline Consumer's price & 10 & 0.96 \\
\hline
\end{tabular}


Table.19 Marketing efficiency (ME) estimated in marketing of Chilli

\begin{tabular}{|c|c|c|c|c|}
\hline \multirow{2}{*}{ Particulars } & \multicolumn{4}{|c|}{ Marketing channels } \\
\cline { 2 - 5 } & I & II & III & IV \\
\cline { 2 - 5 } & & & & \\
\hline Quantity produced and sold (qt) & 2000 & 2400 & 100 & 5900 \\
\hline $\begin{array}{c}\text { Quantity sold (\%) } \\
\text { Value of produce sold (Consumer } \\
\text { price) }\end{array}$ & 6.25 & 75 & 35 & 18.4 \\
\hline Marketing cost (I) (Rs./q) & 125.00 & 242 & 35 & 255 \\
\hline Marketing efficiency (ME=V/I-1) & 3.8 & 1.81 & 15.5 & 1.71 \\
\hline Farmer Price (Rs./q) & 475 & 439 & 564 & 437 \\
\hline $\begin{array}{c}\text { Producer share in consumer's Price } \\
\text { (\%) }\end{array}$ & 79 & 64.4 & 97.2 & 63.1 \\
\hline
\end{tabular}

Table.20 The efficiency of different marketing channels of Brinjal

\begin{tabular}{|c|c|c|c|c|}
\hline \multirow{2}{*}{ Particulars } & \multicolumn{4}{|c|}{ Marketing channels } \\
\cline { 2 - 5 } & I & II & III & IV \\
\hline Quantity produced and sold (qt) & 1500 & 10000 & 500 & 2500 \\
\hline $\begin{array}{c}\text { Quantity sold (\%) } \\
\text { Value of produce sold (Consumer } \\
\text { price) }\end{array}$ & 696 & 68.9 & 3.4 & 17.2 \\
\hline Marketing cost (I) (Rs./q) & 126 & 242 & 630 & 726 \\
\hline Marketing efficiency (ME=V/I-1) & 4.52 & 1.96 & 17 & 1.90 \\
\hline Farmer Price (Rs./q) & 570 & 475 & 580 & 476 \\
\hline Producer share in consumer's Price (\%) & 81.8 & 66.2 & 92.0 & 65.5 \\
\hline
\end{tabular}

Fig.1 Production performance of different Horticultural crops in India

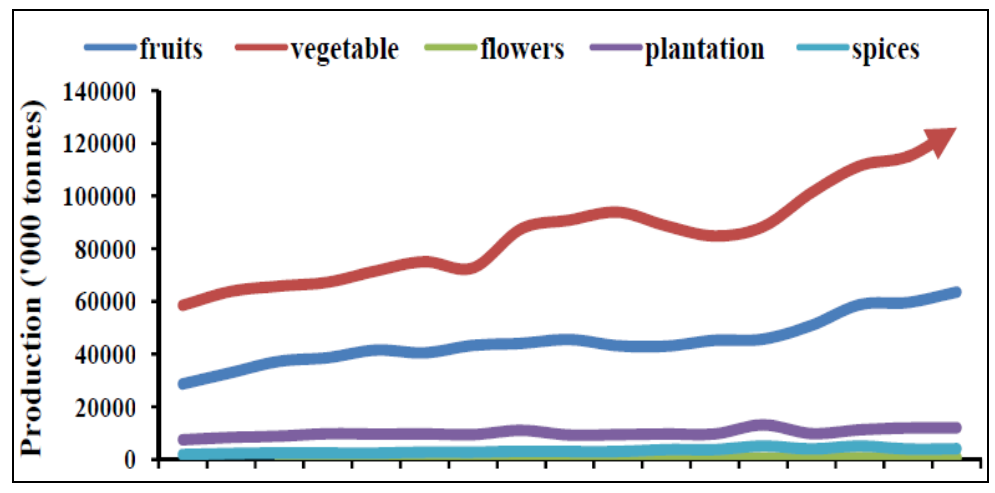


Int.J.Curr.Microbiol.App.Sci (2019) 8(12): 1821-1840

Fig.2 Share of Horticulture (Area-wise)

\section{Share of Horticulture}

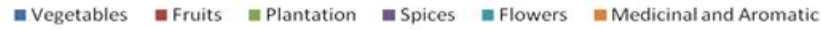

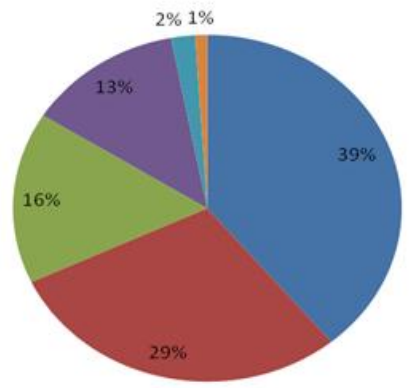

Fig.3 Share of Horticulture (Production-wise)

Production Share of various Horticulture crops

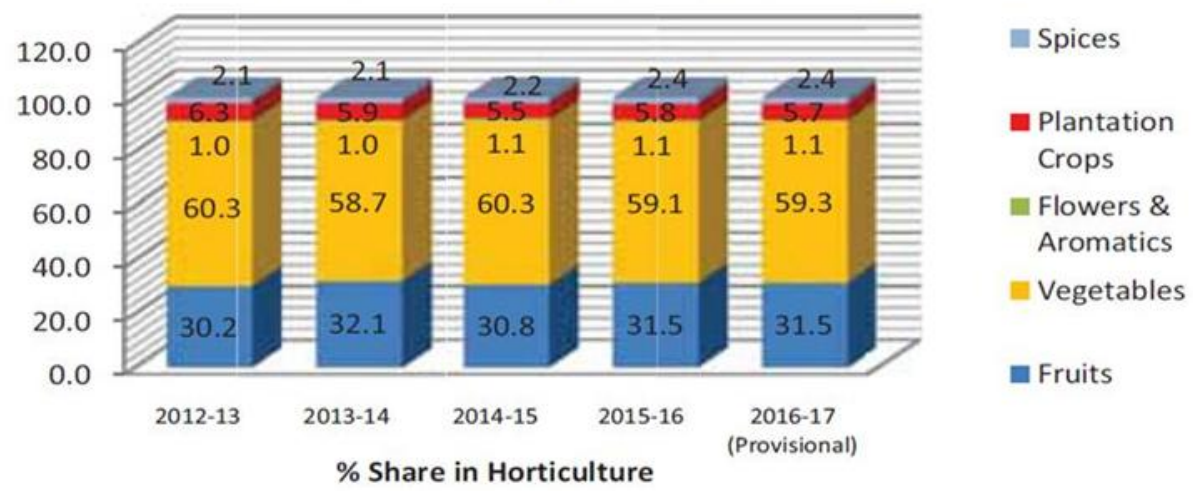

Fig.4 The Seasonality of Prices and Arrival of Tomato

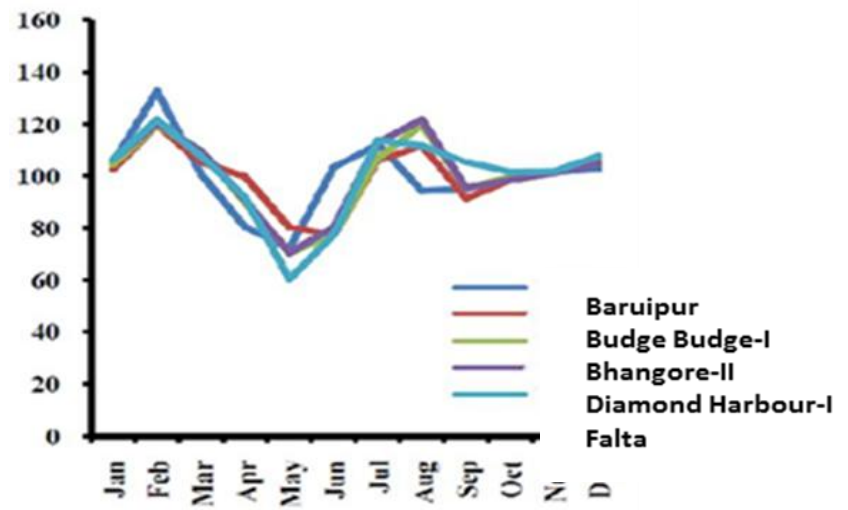


Fig.5 The Seasonality of Prices and Arrivals of Cauliflower

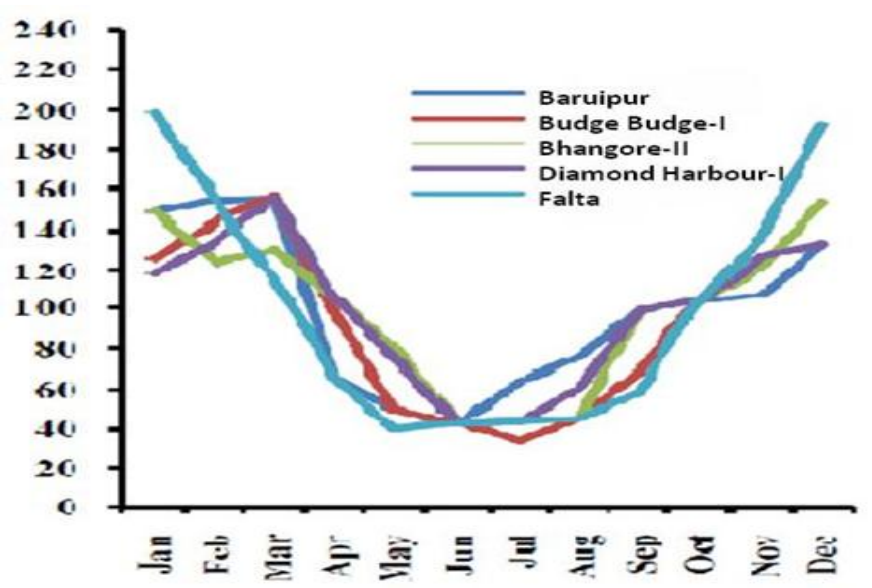

Fig.6 The Seasonality of Prices and Arrivals of Cabbage

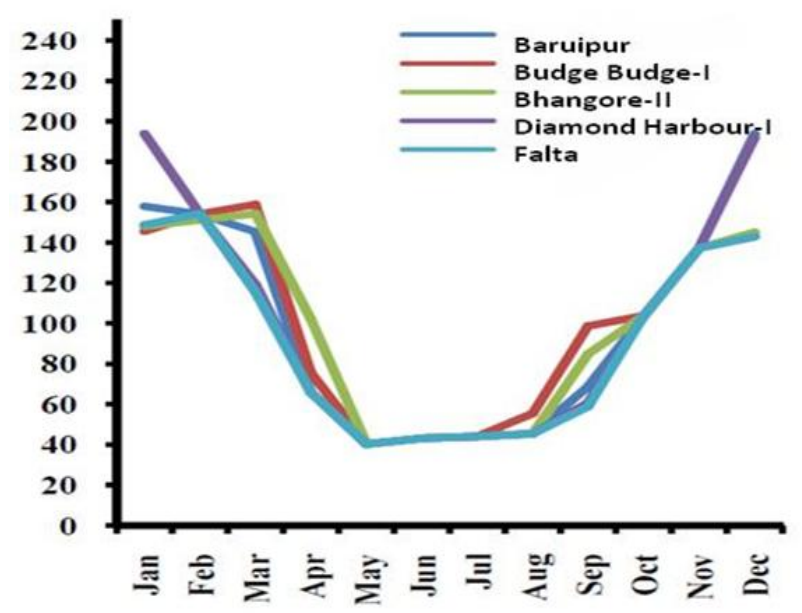

Fig.7 The Seasonality of Prices and Arrivals of Cucurbits

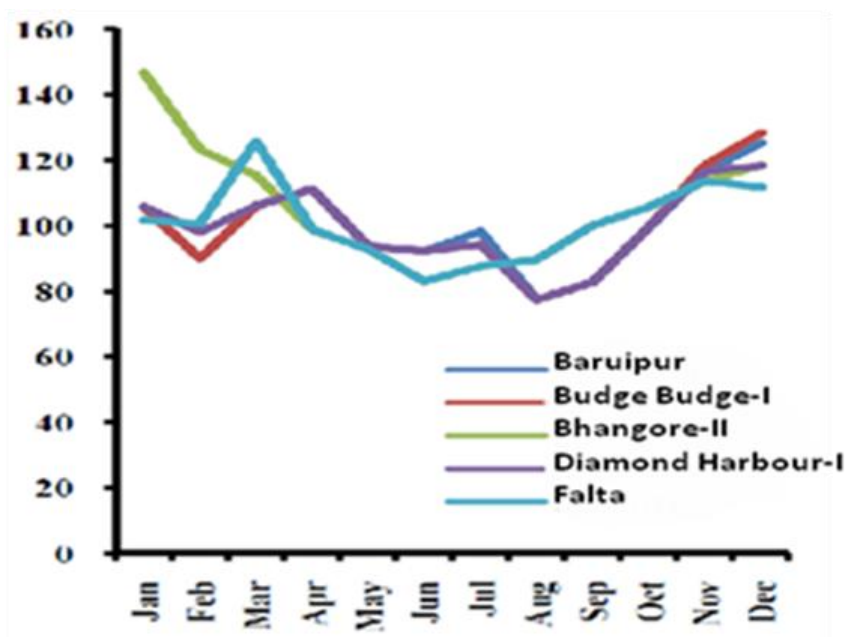


Fig.8 The Seasonality of prices and arrivals of chilli

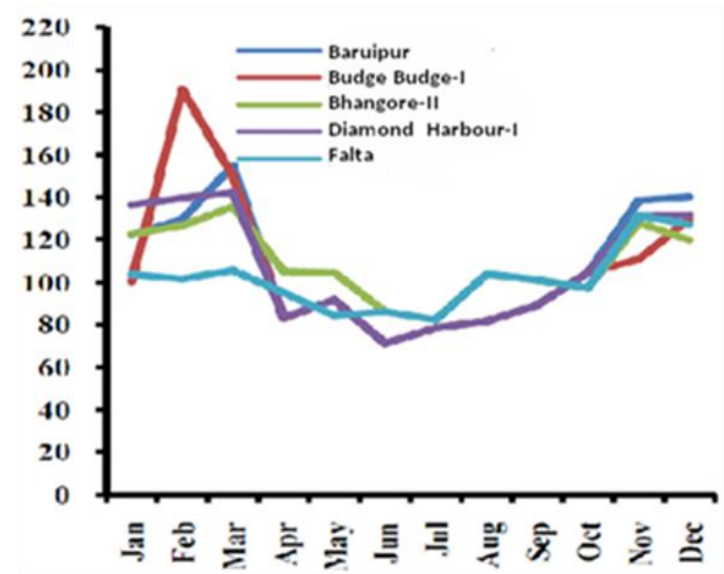

Fig.9 The seasonality of prices and arrivals of brinjal

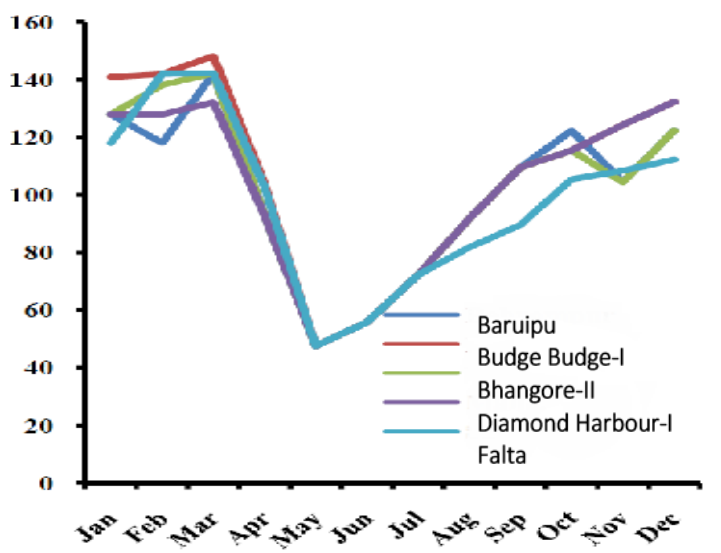

That is, arrivals of Brinjal fluctuated in unsystematic manner except in the months of January to march which showed increasing pattern in arrivals followed by decreasing pattern from May to September. The price index was lower from the month January to June and above the average during the period from August to December (Fig. 9). The main reason for seasonal variation in price was the pattern of market arrivals and the influence of previous period price of Brinjal. The price index was maximum in the month July and it was advisable for producers to sell it from July to December. The highest price level, however, reached in November indicating the presence of greater shortage of this vegetable during this month.
Marketing efficiency is essentially the degree of market performance. A change that reduces the costs of accomplishing a particular function without reducing consumer satisfaction indicates an improvement in the efficiency. But a change that reduces costs but also reduces consumer satisfaction need not indicate increase in marketing efficiency. A higher level of consumer's satisfaction even at a higher marketing cost may means increasing marketing efficiency if the additional satisfaction derived by the consumer out weights the additional cost incurred on the marketing process. An efficient marketing system is an effective agent of change and an important means for raising the income levels of the farmers and the levels of satisfaction of 
the consumers. Efficiency is said to have increased when cost of performing a function for each unit of output is reduced. This can be brought about either by reducing physical losses or through change in the technology of the function i.e. storage, transportation, handling and processing. Marketing margins are the differences between prices paid by the consumer and price received by the producer, Marketing margins include total cost of marketing and the profit or loss accruing to the intermediaries in the process of moving the produce from the farmer to the ultimate consumer. Generally, high marketing costs and margin are considered to be indicators of inefficiency in the marketing process. The geographical location of production brings about a change in the marketing cost. Time of production is another component of marketing cost. Form of products adds to the cost of processing. These costs are often not avoidable. The other important cause of reducing marketing efficiency is the performance of large number of market functionary. Market functionaries or institutions move the commodities from the producers to consumers. Every functions or service involves cost. The intermediaries or middlemen make some profit to remain in the trade after meeting the cost of the function performed. In the marketing of agricultural commodities, the difference between the price paid by consumers and the price received by the producer for an equivalent quantity of farm produce is the farm-retail spread or price-spread. Sometimes, this is termed as marketing margin. The total margin includes (1) the cost involved in moving the product from the point of production to the point of consumptions i.e. the cost of performing the various marketing functions and of operating various agencies, and (b) profit of various market functionaries involved in moving the produce from the initial point of production till it reaches the ultimate consumers. The absolute value of the marketing margin varies from channel to channel, market to market and time to time.

The present study describes the marketing cost of different marketing channel used for Tomato, Cauliflower, Cabbage, Cucurbits, Chilli, Brinjal marketing in the district namely South 24 Parganas of West Bengal which has been selected to study the marketing efficiency of vegetables. Respondents were selected from five blocks namely Budge Budge-I, Baruipur, Bhangore-II, Diamond Harbour-I and Falta for this purpose. Randomly 200 farmers and 50 Wholesalers and 50 Retailers were interviewed from these study. The component of marketing cost such as assembling cost, storage powder cost, grading cost, packaging cost, transportation cost at various levels, and margin of various intermediaries was obtained. The problem faced by farmers, wholesaler, retailer, commission agent, were enquired by direct interview.

For Tomato, Cauliflower, Cabbage, Chilli and Brinjal, the following marketing channels were identified by the selected farmers to dispose off their produce:

$\begin{array}{ll}\text { Channel - I: } & \begin{array}{l}\text { Producers } \\ \text { Retailer } \\ \text { Consumer }\end{array} \\ \text { Channel - II: } & \begin{array}{l}\text { Producers } \\ \text { Wholesaler } \\ \text { Retailer } \\ \text { Consumer }\end{array} \\ \text { Channel - III: } & \begin{array}{l}\text { Producer } \\ \text { Consumer }\end{array} \\ \text { Channel - IV: } & \text { Producer } \\ \text { Commission } \\ \text { Consumer }\end{array}$


Marketing efficiency (ME) estimated in marketing of Tomato crop is presented in Table 10.

It was depicted from Table 10, the marketing efficiency (ME) was much higher in channel III (5.6) than that of channel I (2.2), channel II (1.96) and channel IV (1.82). This revealed that higher marketing margins were taken away by the market intermediaries in the channel I, II and IV resulted in the poor efficiency in the marketing of Tomato. The producers share in consumer rupee is higher in channel III (84\%) followed by the channel I (68\%), channel II (66\%), and channel IV (64\%). It was observed from Table 9 that the maximum quantity of Tomato was marketed through channel II (64\%), followed by channel IV (20.5\%), channel I (11.7\%) and channel III (3.8\%). The maximum quantity of Tomato was sold through channel II, channel IV. Tomato produced in study area are not consumed in same area but are sold in various parts of the country. Tomato growers were not able to sell their total produce in local market because of high production. Price spread of marketing channels II is presented in Table 11.

In the district South 24 Parganas, the marketing of Cauliflower was dominated by middlemen or commission agents. In the marketing of Cauliflower it was observed that, marketing efficiency (ME) was much higher in channel III (12.6) compared of channel I (2.86), channel II (2.16) and channel IV (1.84) depicted in Table 12 whereas price spread of marketing channel II in Table 13. Higher marketing margins were taken away by the market intermediaries just like marketing of Tomato leading to poor efficiency in the marketing of Cauliflower in the study area. It was that observed producers share in consumer rupee was higher in channel III, where no middlemen are involved.

Marketing of Cabbage is done by four channels. The consumer price was comparatively higher in channel IV, than the other channels due to differences in the commission agent's charges, cost of packaging materials etc.

It was observed from Table 14, the maximum quantity of Cabbage was marketed through channel II $(68.2 \%)$, followed by channel IV (15.4\%), channel I (13.2\%) and channel III (3.2\%). Because of the large scale production of Cabbage in the state the maximum quantity was sold through channel II and channel IV. The Prices in marketing channel II has been depicted in Table 15.

Cucurbits are not produced in South 24 Parganas commercially but small quantity of Cucurbits production is there. Following marketing channels were identified for Cucurbits from study area.

$\begin{array}{ll}\text { Channel - I: } & \begin{array}{l}\text { Producers } \\ \text { Wholesaler } \\ \text { Retailer } \\ \text { Consumer }\end{array} \\ & \begin{array}{l}\text { Producers } \\ \text { Wholesaler } \\ \text { Consumer }\end{array} \\ \text { Channel - II: } & \begin{array}{l}\text { Producer } \\ \text { Retailer } \\ \text { Consumer }\end{array} \\ \text { Channel - III: } & \begin{array}{l}\text { Producer } \\ \text { Consumer }\end{array}\end{array}$

Channel - V:

Producer

Commission agent Wholesaler Retailer Consumer

It was noticed from Table 16, that the marketing efficiency (ME) was much higher in channel IV (25) than that of channel III (5.81), channel II (5.04), channel I (3.31) and channel V (3.22). The maximum quantity of Cucurbits was passed through channel I 
(66.4\%) followed by channel V (16.5\%), channel II (7.4\%), channel III (7.5\%) and channel IV (2.2\%) (Table 16). The marketing efficiency of fourth channel was highest due to presence of no intermediary. The maximum quantity sold through channel I, channel V because of the bulky production of Cucurbits. Cucurbits produced in study area is not consumed in same area but also outside state and even in neighboring country also. The Prices spread of Cucurbits in marketing channels has been depicted in Table 17.

Chilli is semi perishable in nature and can be stored in the cold storage for the long time. Therefore, the marketing of Chilli is different from the marketing of Cauliflower, Cabbage and Tomato which are perishable. Generally in the winter season immediately after harvesting, the price of Chilli in the market becomes very low due to glut in production (Table 18). Therefore it is necessary to hold Chilli for some time. Use of storage facilities, chemicals to control sprouting and disease attack during storage makes Chilli marketing costly for the small farmers.

It is depicted from Table 19 that the marketing efficiency (ME) was much higher in channel III (15.5) than that of channel I (3.8), channel II (1.81) and channel IV (1.71). This revealed that higher marketing margins were taken away by the market intermediaries in the channel I, II and IV resulted in the poor efficiency in the marketing of Chilli.

Most of the Brinjal was marketed through channel involving wholesaler, commission agent and retailer. This led to wastage and increased marketing cost (Table 20). The produced share in the consumer rupee was higher in channel III (92\%) followed by the, channel I $(81.8 \%)$, channel II $(66.2 \%)$ and channel IV $(65.5 \%)$.

\section{References}

Ashturker, B.M. and Deole, C.D. 1985. Producers' Share in Consumers Rupee: A Case Study of Fruit marketing in Marathwada. Indian J. Agric. Econ., 40: 3.

CII, Mckinsey Report. 1997. The Fruit and Vegetable Opportunity, In: Food and Agriculture Integrated Development (FAID) Action Report, pp. 140-152.

Gupta, S.P. and Rathore, N.S. 1998. Marketing of Vegetables in Raipur District of Chhattisgarh State: An Economic Analysis. Indian J. Agric. Econ., 53(3): 393.

Mittal, S. 2007. Enhancing the Viability of Small Farms: Diversification through Horticulture Crops (Present Status and Future Scope), Agricultural Situation in India, 54 (1): 29-33.

Saikia, T.N. 1985. Price Structure of Pineapple: A Study in Meghalaya. Indian J. Agric. Econ., 40(3): 119-123.

Sankerlalguru, 2001. Report of Expert Committee on Strengthening and Developing of Agricultural Marketing Government of India, Ministry of Agriculture. Department of Agricultural and Cooperation.

Subrahmanyam, 1989. Economics of cultivation of horticultural crops in South India. Technical bulletin 7, Indian Institute of Horticulture Research, Bangalore-89.

\section{How to cite this article:}

Prasenjit Kundu, Nayan Kishor Adhikary and Abhijit Ghosal. 2019. Vegetables Marketing Scenario and Trends in Prices and Arrivals of Vegetables in Different Markets of South 24 Parganas District of West Bengal, India. Int.J.Curr.Microbiol.App.Sci. 8(12): 1821-1840.

doi: https://doi.org/10.20546/ijcmas.2019.812.218 